\title{
Venice Commission: the role in the process of international and national law interpretation
}

\author{
Associate professor Svitlana KARVATSKA ${ }^{1}$ \\ Associate professor Ivan TORONCHUK ${ }^{2}$ \\ Lecturer Alyona MANYK ${ }^{3}$
}

\begin{abstract}
The article aims to study the Venice Commission's role as one of the leading international law interpreters. This role has gradually strengthened in the process of scientifically substantiated promotion of legal norms and standards concerning democracy, human rights, and the rule of law. Using system-structural, formal-legal, comparative-legal, empirical, and anthropological methods, one has drawn essential conclusions regarding implementing the Venice Commission's interpretive activities. As a result, it has been proved that the nature of the Venice Commission's interpretive activity demonstrates the existence and growing contradiction between the prevailing interpretive practice at the supranational level and the provisions of the classical theory of law interpretation. Ukraine's ongoing dialogue with the Venice Commission is vital to develop and improve legislation, especially laws, implementing new constitutional provisions on justice, the drafts of which have already been designed or are being developed, as well as indubitable compliance with these laws. Venice Commission's general documents should be for the Ukrainian legislator the source to base the preparation of relevant legislation.
\end{abstract}

Keywords Venice Commission, subject of interpretation, interpretive practice, international and national law, legal norms and standards.

JEL Classification: K33

DOI: $10.24818 / \mathrm{TBJ} / 2021 / 11 / \mathrm{SP} / 06$

\section{Introduction}

International law at this stage of development is undergoing serious changes caused by globalization, transformation of values and scientific paradigms. But the phenomenon of international law is that, regardless of its venerable age, international law is a "live", developing legal system. ${ }^{4}$ The formation of a new international legal order in the second half of the XX century was accompanied by the appearance of

\footnotetext{
${ }^{1}$ Svitlana Karvatska - LL. D (Doctor of Law), associate professor, Department of European Law and Comparative Law Studies, Yuriy Fedkovych Chernivtsi National University, Ukraine, s.karvatska@chnu.edu.ua.

${ }^{2}$ Ivan Toronchuk - Ph.D, associate professor, Department of European Law and Comparative Law Studies, Yuriy Fedkovych Chernivtsi National University, Ukraine, i.toronchuk@chnu.edu.ua.

${ }^{3}$ Alyona Manyk - Ph.D, Senior Lecturer, Department of European Law and Comparative Law Studies, Yuriy Fedkovych Chernivtsi National University, Ukraine, a.manyk@chnu.edu.ua.

${ }^{4}$ D'Amato, A., "Groundwork for International Law", American Journal of International Law, vol. 108, 4, (2014): 650-679.
} 
new international law interpretation subjects, influencing the national legal systems as well. The effectiveness of modern international legal order and the improvement of legal practice largely depend on the knowledge of nature and functional role of interpretive practice as an activity to establish the content and form of legal phenomena, taken as a unity with the accumulated interpretive experience. As Francis Fukuyama justly concludes (2015), "respect for the rule of law, and the maintenance of at least reasonably effective rule of law institutions and practices, form central attributes of modern, functioning, legitimate political order". ${ }^{5}$ The activity of the Venice Commission is an example of the new and multi-dimensional global law field. ${ }^{6}$ Therefore, the Venice Commission's national law interpretation is a new phenomenon of international and national legal order. And it is at the present stage of development, that one of the special features of international law transformation, reflecting the main international community's aspirations, is the growing influence of recommended norms, some of which are called "international standards". The Commission actively carries out "intellectual and interpretative activity aimed at comparing those different experiences and drawing principled conclusions from the domestic choices of the European Countries". ${ }^{7}$

Ukraine acquired the Venice Commission of the Council of Europe's full member status after the adoption of the Law on Ukraine's accession to the partial agreement on the European Commission "For Democracy through Law" on December 7, 1996. The Venice Commission's recommendations of general nature, as well as the conclusions on Ukraine, are used as important arguments in shaping the legal positions of Ukraine's Constitutional Court and other judicial authorities. It is obvious that the conclusions of the Venice Commission on constitutional and legislative acts are a real litmus test of whether the chosen path of the state corresponds to European standards and values.

\section{The Venice Commission interpretive activity: doctrinal and applied aspects transformation}

\subsection{Nature of the Venice Commission: law vs. politics}

The Venice Commission Statute, developed by the Council of Europe Committee of Ministers, does not practically provide for a procedure, governing the preparation of conclusions on draft constitutions and quasi-constitutional legislation. It only indicates which organizations can use the Venice Commission's documents, and Member States are responsible for most recommendation requests. In addition, other bodies of the Council of Europe and international organizations may ask the Venice Commission to evaluate the constitutional documents of its members (quasi).

\footnotetext{
${ }^{5}$ Fukuyama, F., "Why is Democracy Performing So Poorly?", Journal of Democracy, vol. 26, No. 1, (2015): 11-20.

${ }^{6}$ Peters, Anne, "The Merits of Global Constitutionalism", Indiana Journal of Global Legal Studies, vol. 16, iss. 2, (2009): 397.

${ }^{7}$ Bartole, Sergio, "International Constitutionalism and Conditionality. The Experience of the Venice Commission", Rivista Associazione Italiana dei Costituzionalisti, vol. 4, (2014), available online at: https://www.rivistaaic.it/images/rivista/pdf/4_2014_Bartole.pdf.
} 
That's why, the countries joining the Commission should be aware, that the Venice Commission can express the essence of the constitutional changes without inquires or even against the wishes of the States. O. Mader notes that "the Venice Commission tends to call rule of law, human rights and democracy the three "basic values" of the Council of Europe" ${ }^{8}$. The rule of law criteria emphasize the instrumental nature of the rule of law; the rule of law is a substantial cultural achievement in human history, but at the same time, it is more than a guarantee of democracy, freedom, and human rights. ${ }^{9}$ According to S. Bartole "democracy is only true if the will of the people is properly expressed in the form of law". ${ }^{10}$ At the time, A. Magen marks, that "as its popularity soared, however, the rule of law became uniquely vulnerable to conceptual over-stretching". ${ }^{11}$

Article 14 provides that, as "a general rule", one or more speakers (elected from among individual members appointed by the state governments) will be commissioned to prepare a draft conclusion on the constitutional arrangements under review. Non-member experts can be invited as advisers. ${ }^{12}$ The Venice Commission is an advisory body. All the documents it prepares belong to soft law. Unlike the provisions of international treaties, which are binding for the acceding states, the documents of the Venice Commission are non-binding and they are not the rules of direct effect: they are of a recommendatory nature and do not provide for any sanctions for non-compliance with the requirements. The European Commission regularly refers to the views of the Venice Commission when assessing whether candidates for the EU membership meet the political preconditions of membership. ${ }^{13}$ Thus, in case of Hungary (2013), the European Commission and the European Parliament relied on the views of the Venice Commission on Hungary's new Basic Law, its amendments and quasi-constitutional laws. The Commission's press release states, that "it is expected that the Hungarian authorities will take due account of the Venice Commission's conclusion on the Fourth Amendment to the Basic Law and will act in full compliance with European Union norms and principles, European rules and values". ${ }^{14}$

${ }^{8}$ Mader, Oliver, "Enforcement of EU Values as a Political Endeavour: Constitutional Pluralism and Value Homogeneity in Times of Persistent Challenges to the Rule of Law", Hague Journal on the Rule of Law, vol. 11, (2019): 133-170.

${ }^{9}$ Fuchs, Michael. "Die Vermessung der Rechtstaatlichkeit - die 'Rule of Law Checklist' der VenedigKommission des Europarates”. Europäische Grundrechte Zeitschrift, 45 (2018): 243.

${ }^{10}$ Bartole, Sergio, Final Remarks: "The Role of the Venice Commission", Review of Central and East European Law, no. 3, (2000): 351.

${ }^{11}$ Magen, Amichai," Cracks in the Foundations: Understanding the Great Rule of Law Debate in the EU”, Journal of Common Market Studies, (2016): 2.

12 Council of Europe, Venice Commission, "Revised Statute of the European Commission for Democracy through Law" (adopted by the Committee of Ministers on 21 February 2002 at the 784th meeting of the Ministers' Deputies). Article 14.

${ }^{13}$ De Visser, Maartje, "A Critical Assessment of the Role of the Venice Commission in Processes of Domestic Constitutional Reform." American Journal of Comparative Law, vol. 63, (4) (2015): 7981, available online at: https://www.venice.coe.int/cocentre/A_Critical_Assessment_of_the_ Role_of the_Venice_Commission.pdf.

${ }^{14}$ European Commission for Democracy through Law (Venice Commission), "Opinion on the Fourth Amendment to the Fundamental Law of Hungary" (Adopted by the Venice Commission at its 95th Plenary Session), Venice, 14-15 June 2013. 
Another striking example is the Parliament's resolution urging the Hungarian authorities to implement the following recommendations as soon as possible, according to the recommendations of the Venice Commission, in order to fully observe the rule of law and its key requirements. As the Venice Commission's reputation strengthens and its membership and activities expand, the fact can't be excluded, that in the future other organizations interested in national constitutional processes may tend to consider its views as a source of empirical or even normative guidance.

One of the main activities of the Venice Commission is aimed at the actual application of constitutional principles, values and cooperation with national constitutional courts. The Venice Commission has a reputation of an authoritative advisory body on constitutionalism and democracy due to the interaction of various factors. The Venice Commission's role began gradually to strengthen in the process of legal standards formation concerning human rights democracy and the rule of law, as well as classical Western European understanding and interpretation of these values. Almost for three decades of its work the Venice Commission succeeded in defining legal norms on a number of crucial directions of legislative development general suffrage and election standards, legislation on judicial system reform, legislation on political parties, improvement of the human rights and the rights of minorities protection mechanisms, constitutional jurisprudence, problems of the state language, etc. The Venice Commission has created a basis of legal conclusions, recommendations, which give chance to speak both of its own interpretation methods formation, and of the whole system of legal principles. The last one finds its reflection in decisions and resolutions of the European Court of Human rights, Council of Europe and European Union bodies, Constitutional Courts and other Supreme state courts.

The Statute of the Venice Commission entrusts it with the improvement of national legal systems mutual understanding in order to approximate these systems, promote the supremacy of law and democracy, and defining the ways to improve the functioning of democratic institutions. The Venice Commission's activity to achieve its goals is versatile. First, the Commission prepares conclusions on constitutions (drafts) and amendments, as well as on legislation within the constitutional framework. Constitutional courts may require amicus curiae, in which the Commission analyzes the constitutional issue under consideration from a comparative and/or international point of view, giving an opinion on the constitutional acts. The Commission also makes recommendations to national ombudsmen through the conclusions of the amicus ombudsman. Secondly, the Venice Commission deals with "transnational issues", i.e. constitutional issues, the relevance of which goes beyond any state. ${ }^{15}$ As a result of national law interpretation the Venice Commission's acts are of recommendatory and explanatory nature, but differ in a number of non-standard characteristics and properties. Obviously, fundamental study of the Venice Commission's activity as a subject of law

${ }^{15}$ Ilkov, Alexander, "The Venice Commission and Ukraine: Ukraine's Path to Democracy through Law”, Parliament Magazine. Scientific and Popular Journal, vol. 3, (2016): 27-32. 
interpretation is important from a scientific point of view, particularly for the modernization theory of law interpretation. ${ }^{16}$ The peculiarities of the Venice Commission's interpretive activity are due to the fact, that a new phase of globalization and interstate integration, which came at the end of the XX century, corresponding trends in international law, convergence of national legal systems led to a paradigm shift, in which lawyers and public authorities previously practiced interpretation, and legal doctrine reflected the accumulated experience. ${ }^{17}$ The Venice Commission's legal interpretation activity is subordinated, first of all, to the goals of law-making, although its results are also used in the field of law realization, including law enforcement. This feature should be emphasized due to the fact that the dogmatic theory of interpretation of law connects it with law enforcement, during which, as a rule, the interpretation was carried out and continues to be carried out by the majority of authorized entities at both national and international levels (e.g., courts - both national and international), as well as lawyers and legal practitioners. The Commission has a unique role in promoting the rule of law and human rights when providing constitutional advice, although it is not easy to evaluate the impact of its work on the national states to which its opinions are directed. ${ }^{18}$

\subsection{The Venice Commission's judicial functions: widening of interpretive activity sphere in modern political processes}

In the process of its interpretive activity the Venice Commission fulfils, actually, several legally important functions. Active systematic consultative activity is a reflection of the nature and essence of the Venice Commission. However, it should be emphasized, that initially the Commission's advocacy activities were transformed both in doctrinal and practical terms, as they began to influence lawmaking and were formed as a new subject of international and national law interpretation. On December 11-12, 2020, the 125th plenary meeting of the Venice Commission took place online. The Commission adopted a conclusion on the Republic of Kosovo Government draft law and a joint opinion of the Venice Commission and the OSCE/ODIHR on constitutional changes of July 30, 2020 and the Electoral Code of October 5, 2020 of Albania. These conclusions were prepared within the framework of the coordination mechanism of the expert services of the European Union and the Council of Europe joint program ${ }^{19}$. On December 11, 2020 an urgent interim conclusion on the draft of Bulgaria's new Constitution; urgent briefing of the amicus curiae on the postponement of the elections, motivated by the constitutional reform of the Kyrgyz Republic; urgent joint briefing of amicus curiae

${ }^{16}$ Riem-Hoffmann, W., "The Venice Commission of the Council of Europe - Standards and Impact", The European Journal of International Law, vol. 25, (2014): 2.

${ }^{17}$ Karvatska, Svitlana, "Determinants of Typical Errors in Interpretation of ECHR Provisions in the Jurisprudence of Ukraine", Journal Transition Studies Review, vol. 28 (1), (2021): 19-30.

${ }^{18}$ Clayton, Richard, "The Venice Commission and the rule of law crisis", Public Law (Thomson Reuters and Contributors), Issue 3, (2019): 460.

${ }^{19}$ Conseil de l'Europe, Commission de Venise, 125 session plénière de la Commission de Venise du Conseil de l'Europe, 11/12/2020 - 12/12/2020. 
on three legal issues related to the mandate of members of the constitutional bodies of the Republic of Moldova; and two urgent opinions on the legislative situation regarding anti-corruption mechanisms and the reform of the Constitutional Court by the decision of the Constitutional Court of Ukraine № 13-r/2020 of 27 October 2020 were also ratified. ${ }^{20}$

An example of an active consultative activity is the Venice Commission's opinion concerning the new Law of Ukraine on the Language of Education, approved by the Supreme Rada of Ukraine on September 5, 2017. The Commission stressed that, although, the reform of the Ukrainian education system is a positive step, the provision of the law, is even discriminatory. The Commission proposed to amend Art. 7 of the Law "On Secondary Education", which would make this provision more balanced. Referring to Art. 13 of the Framework Convention for the Protection of national minorities, the Venice Commission recommended to start a new dialogue with the representatives of national minorities on the language issue in education, so that the law facilitates the preservation of cultural heritage of national minorities and continuity of the language learning in national schools. ${ }^{21}$

One of the main is the function of consolidation and unification of law by combining legal positions of the Venice Commission itself, the ECHR, other bodies of the Council of Europe, ways and methods of interpretation, historically established European standards and practices, constitutional ideas and doctrines. The unification of law by the Commission has been particularly evident in such areas of its activities, as the protection of human rights and freedoms, as well as suffrage (elections, referendums, etc.). In parallel with the ECHR and together with it, the common human rights law has been practically developed through the interpretation and application of the ECHR norms and other similar treaties. On December 8, 2020, the PACE Committee on Legal Affairs and Human Rights requested the Venice Commission to comment on the compatibility of certain European criminal law rules used to prosecute peaceful protesters of the Belarusian "Coordinating Council". The draft opinion will be prepared for adoption at a plenary meeting in March $2021^{22}$.

The exchange of legal ideas and the conclusions of the Commission on individual institutions and branches of law, as well as on transnational issues allow initiating the development of norms and concepts, that can close the gaps in national legislation. At the same time, both national and foreign constitutional experience requires careful treatment based on an understanding of the internal relationship between law, universal and national values. For example, in 2020, the Parliamentary Assembly of the Council of Europe, established by the Council of Europe, requested the Venice Commission's opinion on the situation of 150,000 dismissed civil

${ }^{20}$ Council of Europe, Venice Commission, Official Website, "Recent and Current Events", 11/01/2021. https://www.venice.coe.int/ webforms/events/.

${ }^{21}$ Council of Europe, Venice Commission, "Ukraine - Opinion on the provisions of the Law on Education of 5 September 2017, which concerns the use of the State Language and Minority and other Languages in Education, adopted by the Commission at its 113th Plenary Session Council of Europe", 8-9 December 2017.

${ }^{22}$ Conseil de l'Europe, Commission de Venise, Site officiel, événements, 11/01/2021. https://www. venice.coe.int/webforms/events/ default.aspx?lang=en. 
servants in Turkey. In a statement, the deputies express their concern about the ineffectiveness of domestic legal protection means. The situation of dismissed civil servants in Turkey has deteriorated after the European Court of Human Rights found, that they had domestic remedies to protect their rights. In its report, the Venice Commission called for the establishment of a special committee responsible for examining the appeals of dismissed officials. The commission has so far reinstated only 9,600 of these officials. According to a press release of the Assembly, "this call came immediately after the Universal Periodic Review (UPR) of the UN Human Rights Council on Turkey, held in Geneva on January 28, 2020, during which the member-countries criticized sharply Turkey on various occasions, such as violations of freedom of expression, freedom of the press and freedom of assembly". ${ }^{23}$

An equally important function of the Venice Commission is to participate in the process of national law modernization. O. Qerimi indicates that "in practice, there is often a variance between establishing a scheme of constitutionalism in a country that supposedly aims to establish the rule of law and the maintenance and performance of that constitution in the real world of law and politics." ${ }^{24} \mathrm{~A}$ transnational contribution to national constitutions can take various forms: from aid in constitution drafting to pieces of advice on laws concerning human rights and from measures to safeguard the independence of the judiciary to those designed to secure free and fair elections. ${ }^{25}$

Experts state, that a lot of changes in national law, especially in the constitutions, have occurred due to constant legal monitoring by the Venice Commission. On December 12, 2020, the Constitutional Court of the Republic of Moldova requested from the Venice Commission a certificate of amicus curiae on three issues concerning the constitutional control of legislative procedures in parliament. The draft note amicus curiae is expected to be submitted for adoption at the $126^{\text {th }}$ plenary meeting in March $2021 .^{26}$ On December 24, 2020, the speaker of the Georgian Parliament requested from the Venice Commission two conclusions on the following legislative texts: a draft amendment to the electoral code, the organic law on political associations of citizens and the Parliament Rules of procedure; draft Article 791 of the electoral code (cancellation of party registration). Draft conclusions will be presented for adoption at a plenary meeting in March 2021. The implementation of the development doctrine of universal standards function is traced clearly in case of influence on constitutional law, national legislation and judicial practice.

${ }^{23}$ Tur, Gerard, "The Parliamentary Assembly of the Council of Europe is not concerned with the respect of human rights in Turkey", Economist, 3 Février 2020.

${ }^{24}$ Qerimi, Qerim. "Operationalizing and Measuring Rule of Law in an Internationalized Transitional Context: The Virtue of Venice Commission's Rule of Law Checklist". Law and Development Review, vol.13, issue 1 (2020): 60-61.

${ }^{25}$ Craig, Paul. "Transnational Constitution-Making: The Contribution of the Venice Commission on Law and Democracy," UC Irvine Journal of International, Transnational, and Comparative Law, 2017, vol. 2, 85 .

${ }^{26}$ Conseil del 'Europe Commission de Venise, Commission de Venise, Site officiel, événements, 11/01/2021. https://www.venice.coe. int/webforms/events/default.aspx?lang=en. 
Interpretational activity of the Venice Commission is a peculiar legal phenomenon, because it is a combination of international, professional, doctrinal and other kinds of interpretation. As a result, acts of interpretation based on broad discretion are adopted, aimed at consolidating the approaches of member states, international organizations to the understanding and content of European and international legal standards, and improving national legislation. It's this fact, which helps to gain standardization of the already acknowledged legal definitions, categories and law institutions. For example, the Venice Commission stated that a bill passed in December 2017 in Poland, which allows the sanctioning of judges, further undermines the independence of the judiciary in the country. According to the members of the Commission, the amendments to the laws on the judiciary, adopted by the Polish Lower Chamber on December 20, 2017, could further undermine the independence of the judiciary. The Venice Commission recalled that it had already expressed serious concern about the first package of judicial reforms adopted in 2017, believing that it posed a serious threat to the independence of the judiciary. According to the Venice Commission, this reform created a legal split because the "old" judicial institutions, in fact, refused to recognize the legitimacy of the "new" ones, considering them independent institutions. And the amendments adopted by the Lower House in December could worsen the situation. Reduction of the judges' role in electing the Supreme Court first president, purely formal, is also problematic in the eyes of the Commission, which recommends the Polish parliament not to apply the proposed amendments and to find other solutions. ${ }^{27}$

In the context of the problem under consideration it is necessary to distinguish features of interpretive activity of the Venice commission. First, the objects of interpretation - international agreements, national laws - are ambivalent, sometimes even incorrectly articulated and having a specific political aim. According to V. Volpe, "the Commission's experts comment on the submitted drafts, highlighting strengths and weaknesses under a legal-technical point of view, and assess the conformity of the domestic text with European legal and democratic standards". ${ }^{28}$ In addition, they are a reflection of different legal cultures, have specific features, depending on this or that legal system. "Consumers" of interpretation, through widening the geography of the Commission participants, are often representatives of different cultural and value systems, legal practices. When different and even controversial values and interests collide, it's very important to find out an optimum dialogue between the universal and the regional, the perception of possible peculiarities and exceptions concerning one's own legal picture of the universe.

No secret, that, on the one hand, the Venice Commission is condemned for superfluous politicization, as well as disregard of national peculiarities in different countries. And, on the other hand, - for imperfect methods in the adoption of

${ }^{27}$ The Venice Commission, "Pologne. The novels of judicial reforms inquisitive of the Council of Europe. The Venice Commission of the South, which described the reforms of the Polish government "sapent encore plus the judicial independence", 16/01/2020.

28 Volpe, Valentina. "Drafting Counter-majoritarian Democracy. The Venice Commission's Constitutional Assistance". Heidelberg Journal for International Law, ZaöRV76 (2016): 818 https://www.zaoerv.de/76_2016/76_2016_4_a_811_844.pdf. 
recommendations process, insufficient through conclusions, and, most important, for the lack of proper managing control. The fact that the Venice Commission is not composed of representatives of the member states authorities, but of legal professionals acting as independent experts, should give this institution of the Council of Europe a less politicized and more independent professional status.

It should be noted, that the Charter of the Commission does not contain requirements of objectivity or political neutrality to its members, as in case with international judges. This is the power and weakness of the given body: the strong aspect here is that its opinion is not inflicted, but recommended: it is an expert position, subjective to some extent and, in principle, can change, although it is formed in the process of collective discussions of documents at the plenary meetings of the Commission. ${ }^{29}$ Another issue is the relatively small number of facts confirming the Venice Commission's conclusions being in demand and applied in national legal systems. The plenary sessions of the Commission are nevertheless monitoring these activities and the agenda includes a discussion of previously adopted conclusions. There is, if not full, then partial implementation of the Commission's opinion. And while the Commission cannot influence the practical application of its findings in this or that state, its "soft power" should not be underestimated.

We can also mention the Venice Commission's conclusions, in which it, in fact, gives an interpretation of the current constitutional provisions in the light of European standards. The history of cooperation between the Venice Commission and Ukraine, in this context, contains an opinion on the constitutional aspects of death penalty in Ukraine, adopted in 1997 on the background of severe pressure from the Council of Europe on Ukraine's violation of its obligations, concerning a moratorium on executions and complete abolition of death penalty. An example of an advisory function is the joint interim opinion on the law of Ukraine on condemnation of communist and national socialist (nazi) totalitarian regimes in Ukraine and prohibition of their symbols. Law of Ukraine № 317-VIII is part of the current process of "decommunization" in Ukraine. The opinion stated that the Venice Commission and the OSCE/ODIHR recognized Ukraine's right to ban or even criminalize the use of specific symbols and to promote totalitarian regimes. And since the regulation concerns human rights, in particular the right to freedom of expression, association, assembly and election, legislation must comply with the requirements, established by the ECHR and other regional or international human rights instruments. The opinion emphasizes that, although Law of Ukraine № 317VIII pursues legitimate aims, its provisions do not appear to be precise enough to prevent the test of legality, legitimacy and necessity in a democratic society. According to the remarks, the law is too broad in scope and imposes sanctions that are disproportionate to the legitimate $\mathrm{aim}^{30}$.

${ }^{29}$ Khabrieva, T. Ya., Venice Commission as a Subject of the Interpretation of Law: Monograph (Moscow: Statute, 2018), 110-112.

${ }^{30}$ Council of Europe, Venice Commission, "Joint Interim Opinion on the Law of Ukraine on the condemnation of the communist and national socialist (Nazi) regimes and prohibition of propaganda of their symbols, adopted by the Venice Commission at its 105 th Plenary Session", 18-19 December 2015. 
The conclusion emphasized that the Venice Commission and the OSCE/ODIHR would encourage the Ukrainian authorities to take a "multifaceted" approach to Ukraine's history, allowing them to see their past objectively in order to promote social unity, peace and democracy. To clarify their position, the Venice Commission and the OSCE/ODIHR made the following key recommendations for improving Law № 317-VIII: a) on symbols: for the sake of clarity, as emphasized, the Law should contain a less extensive and exhaustive list of prohibited symbols; b) in relation to propaganda: this concept should be clearly defined, especially when it is used to criminalize behavior; (c) concerning the waiver of crimes: the relevant provisions should relate to specific crimes and not to generalized definitions, such as the regime's "criminal nature" in general, which is too vague; (d) as regards sanctions: only dangerous to society acts shall entail criminal liability, which must be proportionate to the seriousness of the offense, the mere display of a symbol or the use of a name shall not lead to imprisonment; e) concerning the prohibition of associations (especially political parties): the law should specify, that the prohibition of any association is a measure of last resort in exceptional cases.

An illustration of the active coordinated interpretive work of the Venice Commission and the OSCE/ ODIHR is the interpretation and recommendations with regard to Ukraine's plans to abolish electronic declaration requirements for anticorruption activists, introduced by Law № 1975-VIII of March 23, 2017 amending the law "On prevention of corruption", which also raise several serious human rights issues (this has been recognized by a number of public bodies). The joint opinion notes that, the impact that draft laws may have on the activities of civil society organizations, the relevant parties are invited to secure, that draft amendments undergo effective consultation procedures in the development and adoption process to ensure an open and transparent activity, confidence in adopted legislation and relevant government bodies in general.

As a result of analysis to ensure compliance with the Council of Europe standards and other international standards of human rights and OSCE commitments the Venice Commission and OSCE/ODIHR provided the following recommendations:

A. To cancel electronic declarations requirements for anti-corruption activists, introduced by Law № 1975-VIII of March 23, 2017, as provided by the draft law № 6674, and to ensure that the repeal takes effect before the deadline for submission of the first electronic declarations by anti-corruption activists - April 1, 2018 (para 64). ${ }^{31}$

B. To remove new requirements for financial statements presentation and disclosure of information according to the Draft Law № 6674 and 6675 in general,

${ }^{31}$ Council of Europe, Venice Commission, Conclusion № 912/2018, Ukraine - Joint Opinion on the Draft Law № 6674 “On Amendments to Certain Legislative Acts to Ensure Public Transparency of Information on Financial Activities of Public Associations and Use of International Technical Assistance" and on the Draft Law № 6675 "On Amendments to the Tax Code of Ukraine for ensuring public transparency in the financing of public associations and the use of international technical assistance", approved by the Venice Commission at the $114^{\text {th }}$ plenary session, 16 March 2018 para 64 . 
or, at least, significantly reduce them to ensure their full compliance with international standards relating to freedom of association, the right to privacy and non-discrimination, and to ensure that they are based on convincing evidence, that they are necessary in a democratic society and proportionate to a legitimate aim. In particular, public associations should not be subject to stricter financial reporting and disclosure requirements than other non-profit organizations, enterprises or other legal entities, and they should have the same rights as other legal entities (paras 48-49). ${ }^{32}$

C. It was noted, that in case of the introduction of new financial reporting and disclosure obligations for these civil society organizations, significant changes should be made to the sanctions provisions in draft law № 6675 to ensure clarity and proportionality, and also to provide for the possibility of potential errors correction; (in particular, by removing the provision on the loss of non-profit status by the organizations from the list of sanctions or explaining, that such a sanction may be applied by a court in exceptional cases (para 52)..$^{33}$

D. To carry out comprehensive and effective consultations on Draft Laws № 6674 and 6675 at all stages of the legislative process, including the time during the discussions in the Supreme Rada and before their adoption, to ensure full information to civil society organizations affected by this legislation after its coming into force, general public, and to give them the opportunity to express their views in a timely manner before the adoption of bills (para 30). ${ }^{34}$

The joint opinion of the Venice Commission, the Directorate for Human Rights (DHR) of the Directorate General for Human Rights and the Rule of Law (DGI) of the Council of Europe and the OSCE Office on two draft laws, as regards freedom of peaceful assembly guarantees, adopted by the Venice Commission at its 108th plenary session (October 14-15, 2016) is topical on the part of active electoral processes in Ukraine and telling in collective interpretational activity realization. ${ }^{35}$

A number of recommendations were addressed to the Ukrainian authorities in the conclusion. General recommendations for both bills are as follows: the definitions of assembly, provided in both bills, should be narrowed, and the term "event" in these definitions should be replaced by the words "gathering of people for expressive purposes", which is an integral part of the assemblies concept; the concept of spontaneous meetings should be introduced in Draft Law № 3587-1, and the provisions on spontaneous meetings in Draft Law № 3587 should explain why the

\footnotetext{
${ }^{32}$ Council of Europe, Venice Commission, Conclusion № 912/2018, 16 March 2018, paras 48-49.

${ }^{33}$ Council of Europe, Venice Commission, Conclusion № 912/2018, 16 March 2018, para 52.

${ }^{34}$ Council of Europe, Venice Commission, Conclusion № 912/2018, “Ukraine - Joint Opinion on the Draft Law № 6674 “On Amendments to Certain Legislative Acts to Ensure Public Transparency of Information on Financial Activities of Public Associations and Use of International Technical Assistance" and on the Draft Law № 6675", 16 March 2018, para 30.

${ }^{35}$ Council of Europe, Venice Commission, Opinion № 854/2016, "Ukraine - Joint Opinion of the Venice Commission, the Directorate-General for Human Rights (DHR) of the Directorate-General for Human Rights and the Rule of Law (DGI) of the Council of Europe and the OSCE Office for Democratic Institutions and Human Rights (OSCE/ODIHR) on two draft laws on freedom of peaceful assembly Venice Commission at its $108^{\text {th }}$ plenary session”, 18 October 2016.
} 
notification procedure cannot be justified and practically carried out in case of voluntary meetings; art. 2 in both drafts should be revised, except for some categories of meetings in the sphere of the future law ${ }^{36}$.

The Venice Commission also recommended adding a provision stating that, if other legislation imposes stricter restrictions on these categories of assemblies, the law on meetings should be applied. Exceptions regarding the meetings with candidates, parliament members and candidates for President of the Republic should be excluded, since such meetings must be covered by the concept of assembly; provisions concerning the grounds for restricting meetings must be brought into line with art. 39 (2) of the Constitution of Ukraine. The consent to restrictions on freedom of assembly should be excluded from both draft laws; exceptions to the rule, that only courts can impose restrictions on freedom of assembly, must be introduced in both drafts; law enforcement authorities should have the right to impose certain necessary and proportionate restrictions on meetings without a court order. It was noted, that in these draft laws it is advisable to set out the conditions, under which law enforcement agencies may use coercion in certain cases.

The Venice Commission's conclusions analysis made on Ukraine, particularly during 2019-2021 (see the table) indicates the need for urgent qualitative integrated analysis of the given recommendations, relevant laws or legislative initiatives (with subsequent Venice Commission's re-examination), their adoption by the Supreme Rada of Ukraine.

Opinions of the Venice Commission on Ukraine in 2019-2021 ${ }^{37}$

\begin{tabular}{|l|l|l|}
\hline Key questions & Title & Number \\
\hline Rule of Law & $\begin{array}{l}\text { Ukraine - Urgent Joint Opinion of the } \\
\text { Venice Commission and the } \\
\text { Directorate General of Human Rights } \\
\text { and Rule of Law (DGI) of the Council } \\
\text { of Europe on the Legislative Situation } \\
\text { regarding anti-corruption mechanisms, } \\
\text { following Decision N }{ }^{\circ} \text { 13-R / 2020 of } \\
\text { the Constitutional Court of } \\
\text { Ukraine/Urgent opinion on the Reform } \\
\text { of the Constitutional Court }\end{array}$ & 1012/2020 \\
\hline $\begin{array}{l}\text { Justice Amendments } \\
\text { to the Law }\end{array}$ & $\begin{array}{l}\text { Ukraine - Opinion on Amendments to } \\
\text { the Law 'On the Judiciary and the } \\
\text { Status of Judges' and certain laws on } \\
\text { the activities of the Supreme Court and } \\
\text { Judicial Authorities }\end{array}$ & 992018/2020 (2020) 061 \\
\hline
\end{tabular}

${ }^{36}$ Council of Europe, The Venice Commission, "Ukraine - Draft Law n ${ }^{\circ} 3587$ on guarantees for freedom of peaceful assembly and Draft Law no 3587-1 on guarantees for freedom of peaceful assembly in Ukraine", CDL-REF (2016)046-e.

${ }^{37}$ Compiled by authors from the Official Website of the Venice Commission: https://www-venice-coeint.translate.goog/WebForms/documents/by_opinion.aspx?lang=EN\&_x_tr_sl=uk\&_x_tr_tl=en\&_ $\mathrm{x}$-tr_hl=uk\&_x_tr_pto=nui. 


\begin{tabular}{|c|c|c|}
\hline $\begin{array}{l}\text { Principles of activities } \\
\text { of the Supreme Court }\end{array}$ & $\begin{array}{l}\text { Ukraine - Amendments to the legal } \\
\text { framework governing the Supreme } \\
\text { Court and judicial self-governing } \\
\text { bodies }\end{array}$ & $\begin{array}{l}\text { CDL-AD (2019) } 027 \\
969 / 2019\end{array}$ \\
\hline $\begin{array}{l}\text { Reforms of the } \\
\text { Constitutional Court }\end{array}$ & $\begin{array}{l}\text { Ukraine - Opinion on the Draft Law on } \\
\text { Constitutional procedure } \\
\text { Ukraine - Draft law no. 4533-1 on the } \\
\text { procedure for hearing of cases and } \\
\text { implementation of decisions of the } \\
\text { Constitutional Court } \\
\text { Ukraine - Urgent Joint Opinion of the } \\
\text { Venice Commission and the } \\
\text { Directorate General of Human Rights } \\
\text { and Rule of Law (DGI) of the Council } \\
\text { of Europe on the Legislative Situation } \\
\text { regarding anti-corruption mechanisms, } \\
\text { following Decision N }{ }^{\circ} \text { 13-R/2020 of } \\
\text { the Constitutional Court of } \\
\text { Ukraine/Urgent opinion on the Reform } \\
\text { of the Constitutional Court }\end{array}$ & $\begin{array}{l}\text { CDL-AD(2021)006 } \\
22 / 03 / 2021 \\
\text { CDL-REF(2021)016-e } \\
09 / 02 / 2021 \\
\text { CDL-PI (2020) } 019 \\
\text { 1012/2020 }\end{array}$ \\
\hline $\begin{array}{l}\text { Electoral process } \\
\text { Legal status of the } \\
\text { deputy }\end{array}$ & $\begin{array}{l}\text { Amicus curiae brief for the } \\
\text { Constitutional Court of Ukraine on the } \\
\text { early termination of the mandate of } \\
\text { MPs }\end{array}$ & $\begin{array}{lll}\text { CDL-AD (2019) } & \text { 029-e } \\
971 / 2019 & & \end{array}$ \\
\hline $\begin{array}{l}\text { Functioning of the } \\
\text { Ukrainian language } \\
\text { as the state language }\end{array}$ & $\begin{array}{l}\text { Ukraine-Opinion on the Law ensuring } \\
\text { the Functioning of the Ukrainian } \\
\text { language as State Language }\end{array}$ & \begin{tabular}{|lll} 
CDL-AD & $(2019)$ & 032 \\
$960 / 2019$ & &
\end{tabular} \\
\hline $\begin{array}{l}\text { Functioning of the } \\
\text { Political Parties in } \\
\text { Ukraine }\end{array}$ & $\begin{array}{l}\text { Ukraine - Law of Ukraine on Political } \\
\text { Parties in Ukraine }\end{array}$ & $\begin{array}{l}\text { CDL-R 09/02/2021EF } \\
(2021) 006-\mathrm{e}\end{array}$ \\
\hline
\end{tabular}

On January 28, 2021, the Supreme Rada of Ukraine sent for the next first reading the Draft Law № 4533 "On the constitutional procedure" in regard to the increase of minimum quorum for the adoption of the Constitutional Court's decisions. ${ }^{38}$ The Venice Commission at its 126 the Plenary Session (19-20 March 2021) adopted Opinion, in which it positively assessed the proposal to clearly define the limits of the powers of the Constitutional Court, prohibiting it from declaring unconstitutional laws that have not been appealed in the prescribed manner. At the same time, the Venice Commission made several proposals, in particular, regarding the introduction of a gradation of types of disciplinary sanctions for judges of the Constitutional Court, competitive examination of the Constitutional Court judges with the involvement of international experts, the circle of persons having the right to initiate disciplinary proceedings against judges of the Constitutional Court, the

\footnotetext{
${ }^{38}$ Council of Europe, Venice Commission, "Ukraine - Draft law no. 4533-1 on the procedure for hearing of cases and implementation of decisions of the Constitutional Court Supreme Rada of Ukraine", CDL-REF(2021)016-e.
} 
possibility of reviewing decisions of the Constitutional Court in the case of bringing a judge to trial, related to a decision adoption. ${ }^{39}$

It can be assumed, that in the near future the interpretive activity of the Commission will face complex and ambiguous processes, taking place in modern legislature. Thus, a lot of authors state a sharp expansion and change in the spheres of constitutional regulation as objects of interpretation. New constitutions secure the foundations of economic and social life, social function of property, mutual social responsibility, instruments of social partnership, principles of interaction between political parties and the authorities, issues of opposition, previously unknown individual and collective rights, cooperation with other peoples and states, principle of respect for the interests and rights of other peoples and states, rules of relations in international community, etc.

\subsection{Venice Commission: what's to be done to improve the quality of conclusions and strengthen legitimacy?}

The analysis of the Venice Commission's legal interpretation activity showed, that the Commission, forming its own legal position, was not limited strictly to interpretation, but, in fact, specified the existing legal position. In this regard, it can be stated, that the boundaries between interpretation and concretization of law are mobile in the legal interpretation activity of this body, and such phenomena, as "explanation interpretation" and "interpretation-concretization" of law coexist in its practice.

This is not the only example of the formation of new forms and types of legal phenomena in the Commission's activity. Previously they were perceived by legal doctrine as relatively independent, with different essence and content, and, therefore, they were strictly differentiated. Attention should also be paid to the following: 1) a combination of interpretation and evaluation of the legal norm, resulting in an "interpretation-evaluation" phenomenon; 2) a combination of teleological and value interpretation, which allows to put forward a hypothesis about the application of a new method of interpretation - "value-teleological" in the activity of the Commission; 3) a combination of doctrinal, competence and professional interpretation in its legal interpretive acts. This is only a small part of the empirical facts, illustrating the processes of synthesizing various phenomena, subject to a new logic, proceeding according to new "mechanics" laws of legal phenomena interaction. However, it is probably premature to make point-blank statements of the appearance of new "hybrid" phenomena in the practice of the Commission's interpretation of national and international law, regardless of indispensable preconditions. It is quite possible, that we observe only new forms and ways of already known legal phenomena interaction, and not new legal substances. ${ }^{40}$

Obviously, the scope of the Commission's interpretive activities will expand,

\footnotetext{
${ }^{39}$ Council of Europe, Venice Commission, "Ukraine - Opinion on the Draft Law on Constitutional procedure (Draft Law no ${ }^{\circ} 4533-1$ (adopted by the Venice Commission at its $126^{\text {th }}$ Plenary Session, online, 19-20 March 2021.

${ }^{40}$ Khabrieva, T. Ya., Venice Commission as a Subject of the Interpretation of Law, 27-32.
} 
despite the ambiguity of modern political processes, and there will be a deepening of specialization in a number of issues, primarily related to human rights and mechanisms for their protection. The matters in question are the legal regulation of abortion, the use of biometric data, medical intervention, organ transplantation, etc. The Commission notes, that a compilation of its opinions and ECHR decisions on bioethics has been prepared for the drafters of new constitutions inclusive.

The time challenges new demands to national legislation. Nowadays one of the urgent tasks is a legislative ban on the use of scientific and technological advances (nuclear and laser energy, genetic engineering, biomedical technologies, etc.) to the detriment of humanity. The problems of ecology, terrorism, drug addiction, piracy, hostage-taking, internal and external migration need an adequate legislative solution. General principles of such agreements could be enshrined in constitutions. The experience of individual states can also lead to the creation of an international legal norm or system of norms. Some of these issues are probably quite solvable (before their direct constitutional consolidation as a result of a constitutional reform) through international and (domestic) constitutional interpretation. E. Holmøyvik and A. Sanders emphasize that "European states should learn from the challenges to the rule of law in different European states and critically review the constitutional and legal framework of their own national judiciaries." ${ }^{4}$

The variety of interpretation objects, the complication of the Commission's legal interpretation activity content, the modification of its goals and objectives in the course of a specific study - all these circumstances have led to a number of problems, both theoretical and practical. The expansion and specialization of interpretation tools, the enrichment of the Commission's research methodology, the determination of boundaries and levels of national legislation and norms of international law interpretation, the status of legal interpretation activities results, etc. are among them. The ideology of law interpretation is a relatively independent problem in the theoretical and legal characterization of the Commission's legal interpretation activity. The Venice Commission carries out an "evolutionary" interpretation law through the prism of certain legal ideas and principles. To ignore the ideology underlying the Commission's legal interpretation activity means to distort the reality in theoretical reflection.

With the development of scientific knowledge about the Venice Commission's activities, many facts of law interpretation by this body have accumulated, and they do not harmonize with the existing theoretical scheme. This circumstance complicates the characterization of the Commission's legal interpretation activity through the established and familiar to lawyers' postulates and categories of the law interpretation theory. The statement allows proving the fact, that previously substantiated conclusions about the goals, objects, types, methods of law interpretation do not always correspond to the real situation and highlight the need to understand the legal interpretation activities of this body at the theoretical level and modernize the theory of interpretation.

${ }^{41}$ Holmøyvik, Eirik \& Sanders, Anne. “A Stress Test for Europe's Judiciaries”. European Yearbook of Constitutional Law (2019): 309. 


\section{Conclusions}

In conclusion, the Commission's interpretive work is a complex process in terms of content, since it combines features of international, official professional, doctrinal and other types and subtypes of interpretation, which in classical theory of law interpretation are not always considered compatible. And the analysis of the Venice Commission's interpretive activity convinces us, that the Commission is not a law enforcement body. Its status, mission and peculiarities of activity are different - it carries out interpretation in the process of expert-consultative activity. The results of its activities are more focused on lawmaking both within national legal systems and internationally. It's law-making, that is a priority area for using the Commission's legal positions.

The Venice Commission's activity in general and the quantity of legal documents it has developed, of course, have a significant impact on the formation of a common "European constitutional heritage" and on the legal systems of individual member states. The protection and perfect improvement of quality and acceptability of the conclusions, prepared by the Venice Commission in favor of national constitutional norms, requires a better set of procedural rules governing its working methods, and a greater degree of sophistication in defining the common constitutional standards, used to assess the constitutional changes envisaged by the member states. In addition, the Commission must be more attentive to the effects of the increase in the number of non-European states among its members and take steps to ensure, that all its members are treated consistently and with due regard for their equality as democratic nations.

It is quite justified to state the role of the Venice Commission as one of the leading international interpreters of law. The role of the Venice Commission has gradually strengthened in the process of scientifically substantiated promotion of legal norms and standards concerning democracy, human rights and the rule of law, as well as the classical Western European understanding and interpretation of these values. At the same time, with the increase in the composition and scope of the Commission's activities, regional European standards are increasingly being integrated into universal international ones. At the same time, the expansion of the framework of constitutional law, especially in the area of human rights, causes the development of the Venice Commission's spectrum of activities. The specific nature of the Venice Commission's interpretive activity demonstrates the existence and growing contradiction between the prevailing interpretive practice at the supranational level and the provisions of classical, including national, theory of law interpretation. The analysis demonstrates the Venice Commission's considerable discretion in organizing its work, and also illustrates communality of opinions at the usual procedural stages. At the same time, it reveals, that there are unjustified inconsistencies in the method of national constitutional texts substantive assessment, and, accordingly, lost opportunities to give optimal guidance to national drafters are highlighted. 
Ukraine's ongoing dialogue with the Venice Commission is important to develop and improve legislation, especially laws, implementing new constitutional provisions on justice, the drafts of which have already been developed or are being developed, as well as indubitable compliance with these laws. It would also be expedient for Ukraine to use new forms of cooperation. In particular, the Constitutional Court's of Ukraine appeal to the Venice Commission for expert opinions of amicus curiae, followed by its relevant decisions, would significantly increase the degree of public confidence to this institution. The use of reports, guidelines, and other Venice Commission's general documents should be for the Ukrainian legislator the source on which the preparation of relevant legislation is based. Regardless of the critical conclusions and remarks, the Commission is guided by a single goal - to lead Ukraine to a true European democracy through law.

\section{Bibliography}

1. Bartole, Sergio. Final Remarks: "The Role of the Venice Commission". Review of Central and East European Law, no. 3 (2000): 351-363 https://www.venice.coe.int/ files/articles/Bartole_role_venice_commission_E.pdf.

2. Bartole, Sergio. "International Constitutionalism and Conditionality. The Experience of the Venice Commission". Rivista Associazione Italiana dei Costituzionalisti, vol. 4 (2014) available online at: https://www.rivistaaic.it/images/rivista/pdf/ 4_2014_Bartole.pdf.

3. Clayton, Richard. "The Venice Commission and the rule of law crisis". Public Law, Thomson Reuters and Contributors, Issue 3, (2019): 450-460.

4. Conseil de l'Europe, Commission de Venise, 125 session plénière de la Commission de Venise du Conseil de l'Europe 11/12/2020 - 12/12/2020, available online at: https://www.venice.coe.int/webforms/events/?id=2797.

5. Constitutional Court of Ukraine, European Commission for Democracy through Law (Venice Commission) with the support of OSCE Project Coordinator in Ukraine on the occasion of the 24th anniversary of the Constitution of Ukraine and the 30th anniversary of the European Commission for Democracy through Law (Venice Commission), June 25, 2020, available online at: https: //www .osce.org/files/f/documents/2/3/455188.pdf.

6. Council of Europe, The Venice Commission. "Ukraine - Draft Law no 3587 on guarantees for freedom of peaceful assembly and Draft Law no 3587-1 on guarantees for freedom of peaceful assembly in Ukraine", CDL-REF (2016)046-e, https://www.venice.coe.int/webforms/documents/?pdf=CDL-REF(2016)046-e.

7. Council of Europe, Venice Commission, "Revised Statute of the European Commission for Democracy through Law (adopted by the Committee of Ministers on 21 February 2002 at the 784th meeting of the Ministers' Deputies)", available online at: https://www.venice.coe.int/WebForms/pages/?p=01_01_Statute.

8. Council of Europe, Venice Commission, "Ukraine - Draft law no. 4533-1 on the procedure for hearing of cases and implementation of decisions of the Constitutional Court Supreme Rada of Ukraine", CDL-REF (2021)016-e, available online at: https://www.venice.coe.int/webforms/documents/?pdf=CDL-REF(2021)016-e.

9. Council of Europe, Venice Commission, "Ukraine - Opinion on the provisions of the Law on Education of 5 September 2017, which concerns the use of the State Language and Minority and other Languages in Education", adopted by the Commission at its 
$113^{\text {th }}$ Plenary Session, 8-9 December 2017, available online at: https:/www.venice.coe.int/webforms/documents/default.aspx?pdffile=CDL$\operatorname{AD}(2017) 030$-e.

10. Council of Europe, Venice Commission, Opinion No. 1024/2021, "Ukraine - Opinion on the Draft Law on Constitutional procedure (Draft Law no ${ }^{\circ} 4533-1$ (adopted by the Venice Commission at its $126^{\text {th }}$ Plenary Session (online, 19-20 March 2021), available online at: https://www.venice.coe.int/webforms/documents/default.aspx?pdffile= CDL-AD(2021)006-e.

11. Council of Europe, Venice Commission, "Ukraine - Joint Opinion on the Draft Law. Conclusion”, № 912/2018, 16 March 2018, available online at: https://www.venice.coe.int/webforms/documents/default.aspx?pdffile=CDL$\mathrm{AD}(2018) 006-\mathrm{e}$.

12. Council of Europe, Venice Commission, Opinion № 854/2016.” Ukraine - Joint Opinion of the Venice Commission, the Directorate-General for Human Rights (DHR) of the Directorate-General for Human Rights and the Rule of Law (DGI) of the Council of Europe and the OSCE Office for Democratic Institutions and Human Rights (OSCE / ODIHR) on two draft laws on freedom of peaceful assembly Venice Commission at its 108th plenary session", 18 October 2016, available online at: http://www.ucipr.org.ua/publicdocs/VC_PA_R.pdf.

13. Council of Europe, Venice Commission, "Joint Interim Opinion on the Law of Ukraine on the condemnation of the communist and national socialist (Nazi) regimes and prohibition of propaganda of their symbols, adopted by the Venice Commission at its 105th Plenary Session", 18-19 December 2015, available online at: https: //www.venice. coe.int/webforms/documents/?pdf=CDL-AD(2015)041-e.

14. Council of Europe, Venice Commission, "Ukraine - Opinion on the provisions of the Law on Education of 5 September 2017, which concerns the use of the State Language and Minority and other Languages in Education, adopted by the Commission at its $113^{\text {th }}$ Plenary Session", 8-9 December 2017, available online at: https://www.venice.coe.int/webforms/documents/?pdf=CDL-AD(2017)030-e.

15. Council of Europe, Venice Commission. Conclusion № 912/2018, ”Ukraine - Joint Opinion on the Draft Law № 6674 “On Amendments to Certain Legislative Acts to Ensure Public Transparency of Information on Financial Activities of Public Associations and Use of International Technical Assistance" and on the Draft Law № 6675 “On Amendments to the Tax Code of Ukraine for ensuring public transparency in the financing of public associations and the use of international technical assistance", approved by the Venice Commission at the 114th plenary session", 16 March 2018 , available online at: https://rpr.org.ua/wp-content/uploads/2018/03/VeniceCommission e-declaration-bill excerpt.pdf.

16. Council of Europe, Venice $\bar{C}$ Commission. Official Website, Events, 11/01/2021, available online at: https://www.venice.coe.int/webforms/events/default.aspx?lang=fr.

17. Council of Europe, Venice Commission." 125th session of the Venice Commission of the Council of Europe", 11/12/2020 - 12/12/2020, available online at: https://www.venice.coe.int/webforms/events/default.aspx?lang=fr.

18. Council of Europe. The Venice Commission. "Pologne. The novels of judicial reforms inquisitive of the Council of Europe. The Venice Commission of the South, which described the reforms of the Polish government "sapent encore plus the judicial independence". 16/01/2020, available online at: https:/www.ouest-france.fr/ europe/pologne/pologne-les-nouvelles-reformes-judiciaires-inquietent-le-conseil-de-1europe-6692779. 
19. Council of Europe. Venice Commission. "Ukraine - Joint Opinion of the Venice Commission”, Opinion № 854/2016, 18 October 2016.

20. Craig, Paul. "Transnational Constitution-Making: The Contribution of the Venice Commission on Law and Democracy". UC Irvine Journal of International, Transnational, and Comparative Law, vol. 2 (2017): 57-86. Available at: https://scholarship.law.uci.edu/cgi/viewcontent.cgi?article=1012\&context=ucijil.

21. D'Amato A. “Groundwork for International Law". American Journal of International Law, vol. 108, 4 (2014): 650-679.

22. De Visser, Maartje. "A Critical Assessment of the Role of the Venice Commission in Processes of Domestic Constitutional Reform". American Journal of Comparative Law, vol. 63, (4) (2015): (963-1008) 79-81, available online at: https://www.venice.coe.int/ cocentre/A_Critical_Assessment_of_the_Role_of_the_Venice_Commission.pdf

23. European $\bar{C}$ ommission for Democracy through Law (Venice $\bar{C}$ Commission). "Opinion on the Fourth Amendment to the Fundamental Law of Hungary. Adopted by the Venice Commission at its 95th Plenary Session", 14-15 June 2013, available online at: https: //www.venice.coe. int/webforms/documents/default.aspx?pdffile = cdl-ad (2013) 012-e.

24. Fuchs, Michael. 'Die Vermessung der Rechtstaatlichkeit - die 'Rule of Law Checklist' der Venedig-Kommission des Europarates". Europäische Grundrechte Zeitschrift, 45 (2018): 237-244.

25. Fukuyama, F. "Why is Democracy Performing So Poorly?". Journal of Democracy, vol. 26, no. 1 (2015): 11-20.

26. Holmøyvik, Eirik \& Sanders, Anne. “A Stress Test for Europe's Judiciaries”. European Yearbook of Constitutional Law (2019): 290-311.

27. Ilkov, Alexander. "The Venice Commission and Ukraine: Ukraine's Path to Democracy through Law", Parliament Magazine, vol. 3 (2016): 7-80.

28. Karvatska, Svitlana. "Determinants of Typical Erros in Interpretation of ECHR Provisions in the Jurisprudence of Ukraine". Journal Transition Studies Review, vol. 28 (1) (2021): 19-30, available online at: https://doi.org/ 10.14665/1614-4007-28-1-002.

29. Khabrieva, T. Ya. Venice Commission as a Subject of the Interpretation of Law: Monograph. Moscow: Statute, 2018.

30. Mader, Oliver. "Enforcement of EU Values as a Political Endeavour: Constitutional Pluralism and Value Homogeneity in Times of Persistent Challenges to the Rule of Law". Hague Journal on the Rule of Law, vol. 11 (2019): 133-170.

31. Magen, Amichai. "Cracks in the Foundations: Understanding the Great Rule of Law Debate in the EU". Journal of Common Market Studies, (2016): 1-12, available online at: https://www.idc.ac.il/en/schools/government/research/documents/magen-2016jcms-_journal_of_common_market_studies\%20(1).pdf.

32. Peters, Anne "The Merits of Global Constitutionalism". Indiana Journal of Global Legal Studies, vol. 16, iss. 2 (2009): 397-411, available online at: https://www.repository.law.indiana.edu/cgi/viewcontent.cgi?article=1396 \&context=ijgls.

33. Qerimi, Qerim. “Operationalizing and Measuring Rule of Law in an Internationalized Transitional Context: The Virtue of Venice Commission's Rule of Law Checklist”. Law and Development Review, vol.13, issue 1 (2020): 59-94.

34. Riem-Hoffmann, W. "The Venice Commission of the Council of Europe - Standards and Impact". The European Journal of International Law, vol. 25 (2) 2014, available online at: https://www.venice.coe.int/files/articles/Hoffmann-Riem_VeniceCommission_Standards.pdf. 
35. Tur, Gerard. "The Parliamentary Assembly of the Council of Europe is not concerned with the respect of human rights in Turkey", Economist, 03.02.2020, available online at: https://www.econostrum.info/L-Assemblee-parlementaire-du-Conseil-de-1-Europes-inquiete-du-non-respect-des-droits-de-l-homme-en-Turquie_a26442. html

36. Volpe, Valentina. "Drafting Counter-majoritarian Democracy. The Venice Commission's Constitutional Assistance”. Heidelberg Journal for International Law, ZaöRV76 (2016): 811-846), available online at: https://www.zaoerv.de/76_2016/76_ 2016_4_a_811_844.pdf. 